Paideusis

\title{
Achieving Extraordinary Ends: An Essay on Creativity (Sharon Bailin)
}

\section{Murray Elliott}

Volume 3, Number 1, 1989

URI: https://id.erudit.org/iderudit/1073410ar

DOI: https://doi.org/10.7202/1073410ar

See table of contents

Publisher(s)

Canadian Philosophy of Education Society

ISSN

0838-4517 (print)

1916-0348 (digital)

Explore this journal

Cite this review

Elliott, M. (1989). Review of [Achieving Extraordinary Ends: An Essay on

Creativity (Sharon Bailin)]. Paideusis, 3(1), 28-30.

https://doi.org/10.7202/1073410ar

This document is protected by copyright law. Use of the services of Erudit (including reproduction) is subject to its terms and conditions, which can be viewed online.

https://apropos.erudit.org/en/users/policy-on-use/
This article is disseminated and preserved by Érudit.

Érudit is a non-profit inter-university consortium of the Université de Montréal, Université Laval, and the Université du Québec à Montréal. Its mission is to promote and disseminate research.

https://www.erudit.org/en/ 
Sharon Bailin, Achieving Extraordinary Ends: An Essay on Creativity (Dordrecht, The Netherlands: Kluwer Academic Pulblisher, 1988. \$54 (U.S.)

An extraordinary end has been achieved in philosophy of education in Canada. That achievement is the publication by Sharon Bailin of Achieving Extraordinary Ends: An Essay on Creativity. The book has been long overdue. We have had John White's 1968 paper $^{1}$ and Mike Parsons' response ${ }^{2}$ as well as other brief articles. But we have lacked a sustained analysis which traces implications for instruction in different areas of creative endeavour. As a result, speculative psychological accounts of creative process have guided educational practice without challenge or benefit from philosophical scrutiny. Thanks to Sharon Bailin, this lack in our philosophical literature has now been corrected.

Achieving Extraordinary Ends, while perhaps not the definitive work on the topic, does make an important contribution to our understanding. In doing so, it strikes a nice balance, avoiding both skimpiness and excessive detail. With 133 pages of text, the book is long enough to be comprehensive without assuming the proportions of an exhaustive or exhausting tome. In developing her thesis, Bailin avoids the common failing of those authors who by either commission or omission leave the impression that creativity is the exclusive purview of the arts. She does give substantial attention to various forms of the arts as she develops her arguments, but she also deals carefully with other disciplines of human inquiry and expression, frequently science and occasionally mathematics. For she wants an account which is fair to human creativity in whatever area it occurs, not just in certain favoured fields.

In passing, we may note that the book gives no attention to creativity in philosophy or philosophy of education, though there is no suggestion that this neglect implies that creativity does not pertain in the philosophical world. But more on this below.

That the account is developed in the context of diverse disciplines is an important feature of the book. For if as educators we are concerned with education broadly understood, if we are concerned with liberal or general education, and if we are concerned with such topics as critical thinking or creativity, we must be careful to avoid arbitrarily aligning different educational excellences with particular subject areas: e.g., creativity with the arts, critical thinking with the sciences, and expressive facility with languages.

Another major strength of Bailin's book is its sound general thesis. That thesis is that creativity is, fundamentally, a characteristic not of people, nor of their mental or other processes. At root, creativity concerns the products of human enterprise. People are creative people and processes are creative processes because of creative outputs. These outputs may or may not be physical objects. Creative outputs in ceramics or painting involve physical objects, but the creative output of the scientist might be a carefully-formulated theory or an ingeniously-conceived experimental design. People are creative if they come up with creative pots (in ceramics), creative shots (in billiards), creative themes (in literature), creative proofs (in mathematics), etc. It is not by an examination of the people themselves or of any processes or procedures they follow in producing their pots, their shots, or whatever that we know certain people to be creative. It is by their fruits that we shall know them. 
In attempting to characterize creative human products, Bailin must tread carefully between the pitfalls of extremes and this she does. She avoids the position that would claim as creative any performance or product that is welldone, however many times that precise performance or product has been produced previously. She avoids the equally extreme position that would make novelty the sole criterion for creativity. Instead, she carefully defines a position which does justice to the importance of a creative performance or product being in recognizable continuity with past achievements without it being totally bound by the limitations of those achievements.

A judgment that something is creative, she maintains, involves a judgment of its quality. It, thus, becomes essential to the development of her thesis that Bailin tackle that old and thorny question of the objectivity of value judgments. For the thesis would be self-defeating were she to maintain that judging some performance or product as creative is to affirm its merit, and then to hold judgments of merit to be purely subjective (in the sense of arbitrary). It is her position that the disciplines within which creation occurs themselves provide contextual criteria for the objective merit of additional achievements.

This claim carries plausibility as it is developed in the context of artistic expression and of scientific discovery. One wonders, however, whether it would have been as plausible had it been developed in the context of moral assertions or of religious claims. Both the pro-choice and the pro-life positions, to focus on a particularly complex moral question, can claim continuity with past practice and both transcend the restrictions of prior orthodoxy. But which should be appraised as the creative extension of moral understanding, and how can this appraisal be defended? I suspect that Bailin would want to say that the difficulty in knowing which of the alternative views in morality is the creative conclusion is connected with the fact that the rules governing the assessment of moral claims are not entirely established. In disciplines where the assessment rules are firmer, we have a sounder base from which to assess whether a particular output is creative. For established rules, skills, and knowledge are important in creative achievement. Far from inhibiting achievement, these provide a facilitating grounding for achieving both ordinary and extraordinary ends in the discipline in question. Just as abiding by the rule prescribing the side of the road on which one may drive is precisely what frees one to travel at all, so observing the rules of a discipline is part of what enables one to generate significant outputs in that field.

Bailin wants to go further than this. She wants to say that it is the mastery of the rules, skills, and knowledge of a discipline which makes possible "the transcending of some of the rules themselves." 3 Although I confess difficulty in discerning precisely how this occurs, it is clear that she wants to maintain that rule-following and imagination complement each other in some way. What is not immediately apparent is how adding an imaginative element to the analysis transforms plain ordinary rule-breaking into the transcending of rule. Some further elaboration would be appreciated.

I mentioned earlier that the thesis was not developed with reference to philosophy itself. As I noted this omission, I found myself asking whether Bailin's book is itself a creative achievement in philosophy of education and how one would decide whether this is so. That the book represents the achievement of an extraordinary end, I do not dispute. That it is an important piece of 
work and that work is of high quality, I have no doubts. That it is imaginative in the way the details of the account are set forth and that in general the analysis is developed in accord with established rules and standards appropriate to philosophical arguments, I do not deny. And yet I find myself still not quite sure that the book qualifies as a creative achievement. Why should I have a persistent uncertainty when--on her account--the question really ought now to be a closed question? As I reflect on this, I think my bother is rooted primarily in a distinction between the fundamental inspiration for the account and the detailed working out of that inspiration. The detailed working out of the thesis makes the book an important book. But the fact that some central ideas incorporated into its basic thesis occur in prior published and unpublished work seems to count against the appraisal of this book as a creative contribution on the topic. Valuable? Yes. Carefully and thoroughly worked out? Yes. But a creative account? That's different.

Perhaps the book should be appraised not as the development of a creative thesis, but as a creative development of a pre-existing thesis. Whichever, the book is well worth reading for the careful way in which an important thesis is developed and presented. It will prove a useful resource to complement the prevalent psychological literature on the topic.

Murray Elliott, The University of British Columbia

\section{Notes}

${ }^{1}$ J.P. White, "Creativity and Education: A Philosophical Analysis," British Journal of Educational Studies, 16, 1968, 123-137.

${ }^{2}$ MJ. Parsons, "White and Black and Creativity," British Journal of Educational Studies, 19, 1971, 5-16.

${ }^{3}$ p. 106 